\title{
Knowledge-Intensive Services Development in the EU: Forecasts for Selected Countries and Implications for Poland
}

\author{
Bianka Godlewska-Dzioboń, Piotr Klimczyk, Agnieszka Witoń
}

\begin{abstract}
A B S T R A C T
Objective: The first purpose of the article and the underlying research is to identify trends in the development of the knowledge-intensive services (KIS) sector in selected EU countries and to create forecasts of its further growth. The second purpose is to recognize factors that may help or inhibit Poland from drawing upon the experiences of the analysed countries.
\end{abstract}

Research Design \& Methods: We use time-series trend forecasting. Forecasts of the development of the KIS sector in the EU are constructed basing on available time series (2008 - 2017) using the least square method (LSM).

Findings: Knowledge-intensive services are developing with various speed in the EU countries, but an existence of a 'glass ceiling' in the context of a possible level of development can be noted. This 'glass ceiling' is situated on different levels for different groups of countries (higher for the most innovative ones, lower for others). While Poland is on the path of convergence with highly-developed EU countries in respect to the growth of knowledge-intensive services sector, several country-specific factors hinder its ability to enter the path of convergence with the innovation-leaders, thus most probably preventing it from ever reaching the highest 'glass ceiling.'

Implications \& Recommendations: The innovation policy should not only be oriented to support R\&D activities but also support the development of KIS.

Contribution \& Value Added: The added value of the article lies in filling the gap in the literature concerning the analysed issue. The findings may serve as suggestions for creating innovation policy.

\begin{tabular}{ll}
\hline Article type: & research article \\
& convergence; innovative services; knowledge-intensive services; Eu- \\
Keywords: & ropean Union; Polish economy \\
JEL codes: & O33, O38
\end{tabular}

Received: 30 August 2018

Revised: 6 March 2019

Accepted: 7 March 2019

\section{Suggested citation:}

Godlewska-Dzioboń, B., Klimczyk, P., \& Witoń, A. (2019). Knowledge-Intensive Services Development in the EU: Forecasts for Selected Countries and Implications for Poland. Entrepreneurial Business and Economics Review, 7(2), 101-118. https://doi.org/10.15678/EBER.2019.070206 


\section{INTRODUCTION}

Modern economies are based on knowledge and information. Knowledge and information are recognized as the driver of productivity and economic growth. The term 'knowledgebased economy' stems from this fuller recognition of the place of knowledge and information in modern economies.

One of the elements of knowledge-based economy is a dynamic development of knowledge-intensive services (KIS) (Wyszkowska-Kuna, 2016). The areas of KIS are characterised by large involvement in research and development ${ }^{1}$ (Doloreux, Shearmur, \& Rodriguez, 2015) and employment of highly educated workforce. The knowledge resource held by the service provider and innovation are necessary conditions for the activity to be included in KIS category. These services may be provided as part of business activity or obtained from specialised third-party companies. KIS is, therefore, capital and knowledge-intensive. These services are a vital source of innovation for businesses and entire economy. Knowledge-intensive services contribute not only through the diffusion of knowledge and innovation to the creation and transfer of modern technology but also to an increase in productivity (Musolesi, \& Huiban, 2009, p. 63) and thus to acceleration of economic growth (Klaesson, \& Norman, 2015, p. 158).

An increase in the number and influence of knowledge-intensive business services (KIBS) in the EU can be attributed to several factors. First, there is an increasing need for knowledge within the economy. Increasing research and development is seen as a significant venue towards the attainment of this objective. Second, the strategies put in place by most governments in the region offer a conducive environment for the increase in KIBS (Pauceanu, 2015, p. 12). In Poland and other CEE countries, a rapid growth of KIS can be seen after 1989 (Baláž, 2004, p. 1).

The purpose of the article is to show trends in the development of the knowledgeintensive services (KIS) sector in selected EU countries and to create projections of its further growth. The second purpose is to identify factors that may help or inhibit Poland from drawing upon the experiences of the analysed countries. To fulfill those aims, we verify the main hypothesis, which is as follows: the process of development of knowledge-intensive services has a certain limit that cannot be overcome, which can be called a 'glass ceiling'. Furthermore, three additional hypotheses were developed: (1) The level of the proposed 'glass ceiling' of knowledge-intensive services development varies in particular economies; (2) The knowledge-intensive services sector is characterised by decreasing marginal productivity; (3) Knowledge-intensive services sector in Poland is on the path of convergence with highly-developed EU countries.

To verify these hypotheses we use time series trend forecasting of the development of the KIS sector in the EU countries.

\footnotetext{
${ }^{1}$ A study carried out by Masso and Vather (2012) concludes that, although knowledge-intensive services (KIS) spend more on research and development (R\&D) the efficiency of turning R\&D expenditures into innovation is higher in less knowledge-intensive sectors.
} 


\section{LITERATURE REVIEW}

In the literature of the subject, two concepts are often used interchangeably: knowledgeintensive services (KIS) and knowledge-intensive business services (KIBS). The difference between them is that knowledge-intensive business services (KIBS) are the sub-group of KIS. In the literature, KIBS are defined as firms that provide knowledge-intensive goods and services for other business firms (Schricke, Zenker, \& Stahlecker 2012, p. 6). Thus, KIBS include all KIS, except for education, health and social work, recreational, cultural, and sporting activities, which are services destined for consumers (Wyszkowska-Kuna, 2016).

The origins of the research on KIS dates back to the 1990s of the last century (Miles et al., 1995). According to this author, 'Knowledge-Intensive Business Services involve economic activities which are intended to result in the creation, accumulation, or dissemination of knowledge' (Miles et al., 1995, p. 18). They act as transmitters of knowledge, contributing in different ways to the innovation processes of related firms (Miles et al., 1995, pp. 41-42). Currently, applicable definitions of KIS and KIBS have some common features, focusing on the high involvement of excellent work (requiring a high level of knowledge), a diffusion process and a significant impact on innovative activities within the enterprise and the economy (Gallego \& Maroto, 2015; Dubosson \& Fragniere, 2008). Concluding, knowledge-intensive business services (KIBS) are:

- performed by private companies and organisations,

- relying on professional knowledge, related to a specific (technical) discipline or (technical) functional domain,

- supplying intermediate products and services that are knowledge-based (Bilderbeek et al., 1998).

KIS are key players in innovation systems, particularly in advanced regions where manufacturing competitiveness depends on knowledge contents provided by highly specialised suppliers (Braga, Marques, \& Serrasqueiro, 2018 p. 360).

Among the determinants of the development of the KIS sector one can mention (Miles et al., 2018):

- growing demand from organisations that focus on 'core competences', outsourcing non-core activities to specialised suppliers,

- increasing requirements for external knowledge,

- changing environments and technologies which require knowledge to fully utilise them,

- growing complexity of economies and the technologies which are deployed in them.

Nowadays, many authors develop the concept of knowledge-intensive services. Full review of authors, publications, topics, and the number of citations is included in a study by Figueiredo et al. (2017). The three most-quoted authors are: Miles, Hertog and Muller, and the four most frequently quoted articles are by Muller and Zenker (2001), Hertog (2000), Miles (2005) and Bettencourt et al. (2002).

Many studies focus on spatial variation of innovation in the knowledge-intensive business sector. The subject of their analysis is the regional diversification of companies in the KIS sector (Brenner et al., 2018; Dolores \& Shearmur, 2012; Klaesson \& Norman, 2015; Pauceanu, 2015; Ženka et al., 2017). The mentioned articles analyse the KIS in some countries (Sweden, Germany, the Czech Republic). Only Alexandrina Pauceanu (2015) presents KIS in all countries 
of the EU. As a continuation of our research on the service sector (Godlewska-Dziobon, Klimczyk, \& Witoń, 2018), in this article we follow the above mentioned research and also focus on the KIS topic from the point of view of the service structure. We want to present the current KIS situation and its share in the EU countries, but our added value is forecasting changes of KIS and their implications for the Polish economic policy.

According to Rodriguez (2014), studies of KIS can be classified into three groups depending on their main objective. The first group contains works that link regional innovation efficiency and KIBS (i.e. Brenner et al., 2018; Gallego \& Maroto, 2015). The second group of authors and we focus on the location of KIS (Pauceanu, 2015; Ženka et al., 2017). The third group of publications addresses how regional features affect the formation of KIS (Dolores \& Shearmur, 2012).

There seems to be an agreement in literature that knowledge intensive (business) services can contribute to economic growth, either regional or national (Brenner et al., 2018; Desmarchelier, Djellal, \& Gallouj, 2013). Knowledge intensive business services provide advanced technological knowledge directly to other industrial sectors, and indirectly to the whole economy (Castellacci, 2008; Radovanović, Dmitrović, \& Žarkić Joksimović, 2017). The economy can benefit collectively from the knowledge produced by KIBS (Brenner et al., 2018). The contribution of KIBS to the productivity of the other industrial sectors may well exceed the productivity gains as measured within the KIBS sector itself (Castaldi, 2009).

However, the relationship between KIS/KIBS and economic growth is two-way. There is a strong demand-pull mechanism in place. Growth in the rest of the economy causes KIBS to grow in the next or later years (Brenner et al., 2018). Therefore, the development of the KIS/KIBS sector in the most developed EU economies is limited due to the slowdown in economic growth. Additionally, according to Baumol (2002) and Wolff (2002), intellectual work is stagnant - the rise in costs is nowhere near being balanced by the improvement in the 'act of thinking'. This causes productivity decreases in knowledge-intensive sectors. What is more, some KIS/KIBS firms follow their clients overseas, and/or seek new markets in (especially) emerging economies. A possible trend is likely to be the emergence of KIBS firms within emerging economies - catering to local and/or world markets (Miles, 2018). Having considered this, we proposed the main hypothesis of the study, which posits that the process of development of knowledge-intensive services has a certain limit that cannot be overcome, which can be called a 'glass ceiling'. The exact level of that limit should be analysed in further studies.

\section{MATERIAL AND METHODS}

Sector development of knowledge-intensive services is measured as employment in KIS in relation to all employment in the economy. The data was obtained from the Eurostat's database. The data source is the European Labour Force Survey (LFS). The definition of knowledgeintensive services used by Eurostat is based on a selection of relevant items of NACE Rev. 2 on a 2-digit level and is oriented to the ratio of highly qualified workers in these areas.

In the course of study, the following hypotheses were developed: The main hypothesis: The process of development of knowledge-intensive services has a certain limit that cannot be overcome, which can be called a 'glass ceiling'. Additional hypotheses were developed: 
1. The level of the proposed 'glass ceiling' of knowledge-intensive services development varies in particular economies;

2. The knowledge-intensive services sector is characterised by decreasing marginal productivity;

3. The knowledge-intensive services sector in Poland is on the path of convergence with highly-developed EU countries.

The available data include the years 2008-2017 and that period was used to build predictions about the development of the KIS sector in the European Union. The length of the available time-series must be considered a limitation of the study, and it needs to be taken into account when perusing the results. Additionally, this method does not identify factors causing the 'glass ceiling' in KIS. This issue should be addressed in further studies. Forecasts were constructed using the method of least squares. The method of least squares is a standard approach in regression analysis to approximate the solution of overdetermined systems. The principle of least squares regression states that the best choice of this linear relationship is the one that minimises the square in the vertical distance from the $y$ values in the data and the $y$ values on the regression line (Watkins, 2016, p. 37). This leads to a minimisation problem for:

$$
S S(\alpha, \beta)=\sum_{i=1}^{n} \epsilon_{i}^{2}=\sum_{i=1}^{n}\left(y_{i}-\left(\alpha+\beta x_{i}\right)\right)^{2}
$$

This approach - with the use of econometric models to forecast socio-economic - is known as a classical statistical approach (Wilks, 2006, p. 217). It is used in cases in which the course of the testing phenomenon is regular over time, and the observed trend is permanent and can be described with a smooth mathematical function. It is assumed that the regularity governing the testing phenomenon will not change significantly during the period for which the forecast is based. The predictions reach the year 2025, but their accuracy decreases as the time horizon progresses.

It was initially assumed that the time series equations would be evaluated in the form of second-degree polynomials:

where:

$$
\hat{z}_{i t}=\alpha+\beta_{1} * t^{2}+\beta_{2} * t
$$

$\hat{z}_{i t}$ - ind involvement of employment in the KIS sector in the country $i$ in the year $t$;

$t$ - time variable;

$\alpha$ - constant;

$\beta_{1}, \beta_{2}$ - structural parameters.

In some cases, for a better fit of the model, statistically insignificant at least at the level $\alpha=0.1$ independent variables appearing in the estimation process were abandoned (time variable or its square) and eventually, linear time series were obtained. The estimated equations for all EU countries are included in Table 1.

The degree of the fit of the model was different for different countries. The model's fit is assessed by the coefficient of determination $R^{2}$. The value of this coefficient shows what part of the variation in the response variable is due to the fit of the model. The rest $\left(1-R^{2}\right)$ is due to the residuals. The $R^{2}$ can be interpreted as the proportion of the variation of the predictand that is described or accounted for by the regression (Wilks, 2006, p. 186). R2 is calculated in the following way (Watkins, 2016, p. 43): 
where:

$$
R^{2}=\frac{\sum_{1=1}^{n}\left(\hat{y}_{i}-\bar{y}_{i}\right)^{2}}{\sum_{1=1}^{n}\left(y_{i}-\bar{y}_{i}\right)^{2}}
$$

$\hat{y}_{i}$ - are the theoretical values of the dependent variable (calculated with the model);

$y_{i}$ - are empirical values of the dependent variable.

The coefficient of determination $R^{2}$ was 0.990 in the case of Sweden, 0.978 in the case of Portugal, 0.964 in the case of Finland, and 0.968 in the case of Bulgaria. On the other hand, in the case of Germany $R^{2}$ was only 0.342 , and in the case of Lithuania - 0.391, which proves a weak model match for these countries. A complete exception was the Netherlands, for which the created model has no prognostic value $\left(R^{2}=0.047\right)$.

Calculated residual variability coefficient (indicating how much of the average value of the explanatory variable is the deviation of the residual component) was for below $3 \%$ all the countries, which suggests that the development of KIS in the selected countries is very slightly affected by random factors.

The usability of the forecasts constructed by the estimated trends is determined by their accuracy, measured with an ex-ante forecast error. It was calculated as a quotient of the forecasted value and its standard error. The obtained results allow to determine most forecasts as accurate (relative error ex-ante $<5 \%$ ), however, in some cases it is necessary to reject forecasts for further years. Too high ( $>5 \%$ ) relative errors of the forecast were observed: for Bulgaria from the year 2024, Denmark from the year 2022, for Estonia from the year 2019, for Greece from the year 2021, for Spain from the year 2021, for Ireland from the year 2021, for Luxembourg throughout the analysed period, for Poland from the year 2024, for Portugal from the year 2022, for Romania in the year 2025, for Slovenia from the year 2022, for Hungary from the year 2022, and for Italy from the year 2023.

To verify the second hypothesis, in the further part of the study the productivity in the KIS sector was analysed in individual years. In this case, due to the limited availability of the data, the testing period is restricted to 2008-2014. The productivity of the sector was measured as the production value for every euro of personnel costs. In this section, the analysis was carried out only for the knowledge-intensive high-technology services.

The last part of the study draws conclusions for the Polish KIS sector and assesses the opportunities and threats it faces.

\section{RESULTS AND DISCUSSION}

During the analysis period 2008-2017, in almost all the EU countries, the development could be observed in the knowledge-intensive services sector. In the whole EU (28 countries) employment in the KIS sector increased three percentage points in the years, from $37 \%$ to $40 \%$. This is slightly less than the average change for all the EU countries (3.36 percentage points). Of course, the situation developed differently for different groups of countries. In the group of Innovation Leaders according to Innovation Scoreboard 2018 (Sweden, Denmark, Finland, the Netherlands, the United Kingdom, and Luxembourg), the average share of employment in the KIS sector has grown by only 0.88 percentage points from $47.37 \%$ to $48.25 \%$. In the group of Strong Innovators (Germany, Belgium, Ireland, Austria, France, and Slovenia) the average share of employment in the KIS sector increased 
by 3.43 percentage points from $38.9 \%$ in 2008 to $42.33 \%$ in 2017 . The most dynamic development of the KIS sector has been observed in Moderate Innovators (Czech Republic, Portugal, Malta, Spain, Estonia, Cyprus, Italy, Lithuania, Hungary, Greece, Slovakia, Latvia, Poland, and Croatia): by 4.42 percentage points from $31.54 \%$ to $35.96 \%$. In turn, in the group of Modest Innovators (Bulgaria, and Romania) the average share of employment in the KIS sector increased by 3.1 percentage points from $23.1 \%$ to $26.2 \%$. In the case of Poland, an increase in the share of the KIS sector in total employment amounted to three percentage points from $28.3 \%$ in 2008 to $31.3 \%$ in 2017 . Special cases were Luxembourg and the Netherlands, countries characterised by a high level of development of the KIS sector (the share in employment in $201748.5 \%$ and $45 \%$, respectively). where, in the analysed period, there was a decrease in the employment share in this sector, 5.7 percentage points and 1.9 percentage points, respectively. In particular, in the case of Luxembourg, this decrease can be explained by a change in factors directly related to the definition of knowledge-intensive services. In the years 2015-2017, when the share of KIS in total employment began to decline in Luxembourg, a decrease in the share of the population with higher education and a simultaneous increase in employment was also seen. Employment in other sectors was characterised by higher dynamics than employment in the KIS.

As mentioned, in almost all the EU countries (and the European Union as a whole) knowledge-intensive services are developing, which is illustrated by the increasing share of this sector in total employment. However, the analysis of the constructed forecasts shows that the achieved increments are getting smaller. The determined trend lines (Table 1 ) indicate that some of the analysed countries have already reached the maximum level of the share of employment, corresponding to the conditions characterising the country. The other surveyed countries will soon reach this level, after which employment in KIS may start to decline.

Table 1. Functions of employment trends in KIS in the European Union countries (as \% of total employment)

\begin{tabular}{|l|l|c|c|}
\hline \multicolumn{1}{|c|}{ Country } & \multicolumn{1}{|c|}{ Trend function } & $\begin{array}{c}\text { Coefficient of } \\
\text { determina- } \\
\text { tion } \mathbf{R}^{2}\end{array}$ & $\begin{array}{c}\text { Residual } \\
\text { variability } \\
\text { factor (in \%) }\end{array}$ \\
\hline Belgium & $\hat{\mathrm{z}}_{\mathrm{BEt}}=45.12+0.343636 * \mathrm{t}$ & 0.894673 & 0.805 \\
\hline Bulgaria & $\hat{\mathrm{z}}_{\mathrm{BGt}}=25.93-0.075 * \mathrm{t}^{2}+1.20682 * \mathrm{t}$ & 0.967816 & 0.899 \\
\hline Czech Republic & $\hat{\mathrm{z}}_{\mathrm{CZt}}=30.2067+0.313333 * \mathrm{t}$ & 0.801868 & 1.566 \\
\hline Denmark & $\hat{\mathrm{z}}_{\mathrm{DKt}}=45.2717-0.133712 * \mathrm{t}^{2}+1.52114 * \mathrm{t}$ & 0.777567 & 1.295 \\
\hline Germany & $\hat{\mathrm{z}}_{\mathrm{DEt}}=39.3333+0.108485 * \mathrm{t}$ & 0.341760 & 1.211 \\
\hline Estonia & $\hat{\mathrm{z}}_{\mathrm{EEt}}=31.4583-0.082197 * \mathrm{t}^{2}+1.21386 * \mathrm{t}$ & 0.665089 & 2.599 \\
\hline Ireland & $\hat{\mathrm{z}}_{\mathrm{IEt}}=39.2067-0.159091 * \mathrm{t}^{2}+2.03788 * \mathrm{t}$ & 0.887204 & 1.368 \\
\hline Greece & $\hat{\mathrm{z}}_{\mathrm{GRt}}=30.63-0.0886364 * \mathrm{t}^{2}+1.435 * \mathrm{t}$ & 0.905916 & 1.613 \\
\hline Spain & $\hat{\mathrm{z}}_{\mathrm{ESt}}=29.8667-0.131818 * \mathrm{t}^{2}+1.86879 * \mathrm{t}$ & 0.924267 & 1.500 \\
\hline France & $\hat{\mathrm{z}}_{\mathrm{FRt}}=42.6867+0.375152 * \mathrm{t}$ & 0.945131 & 0.649 \\
\hline Croatia & $\hat{\mathrm{z}}_{\mathrm{HRt}}=27.02+0.809091 * \mathrm{t}$ & 0.935005 & 2.177 \\
\hline Italy & $\hat{\mathrm{z}}_{\mathrm{ITt}}=33.54+0.118182 * \mathrm{t}$ & 0.922556 & 0.322 \\
\hline Cyprus & $\hat{\mathrm{z}}_{\mathrm{CYt}}=33.4933+0.641212 * \mathrm{t}$ & 0.823784 & 2.573 \\
\hline Latvia & $\hat{\mathrm{z}}_{\mathrm{LVt}}=33.4267+0.37697 * \mathrm{t}$ & 0.681614 & 2.331 \\
\hline Lithuania & $\hat{\mathrm{z}}_{\mathrm{LTt}}=32.0667+0.23697 * \mathrm{t}$ & 0.390587 & 2.848 \\
\hline Luxembourg & $\hat{\mathrm{z}}_{\mathrm{LUt}}=51.2833-0.285606 * \mathrm{t}^{2}+2.59682 * \mathrm{t}$ & 0.814755 & 2.715 \\
\hline Hungary & $\hat{\mathrm{z}}_{\mathrm{HUt}}=32.5667-0.0590909 * \mathrm{t}^{2}+0.877879 * \mathrm{t}$ & 0.821856 & 1.240 \\
\hline
\end{tabular}




\begin{tabular}{|l|l|c|c|}
\hline \multicolumn{1}{|c|}{ Country } & \multicolumn{1}{|c|}{ Trend function } & $\begin{array}{c}\text { Coefficient of } \\
\text { determina- } \\
\text { tion R }\end{array}$ & $\begin{array}{c}\text { Residual } \\
\text { variability } \\
\text { factor (in \%) }\end{array}$ \\
\hline Malta & $\hat{\mathrm{z}}_{\mathrm{MTt}}=38.8+0.832727 * \mathrm{t}$ & 0.900125 & 2.053 \\
\hline Netherlands & $\hat{\mathrm{z}}_{\mathrm{NLt}}=46.2267-0.0484848 * \mathrm{t}$ & 0.047488 & 1.517 \\
\hline Austria & $\hat{\mathrm{z}}_{\mathrm{ATt}}=35.4+0.338182 * \mathrm{t}$ & 0.824473 & 1.345 \\
\hline Poland & $\hat{\mathrm{z}}_{\mathrm{PLt}}=27.6883-0.0541667 * \mathrm{t}^{2}+0.881288 * \mathrm{t}$ & 0.937294 & 0.923 \\
\hline Portugal & $\hat{\mathrm{z}}_{\mathrm{PTt}}=26.47-0.0643939 * \mathrm{t}^{2}+1.6053 * \mathrm{t}$ & 0.978161 & 1.425 \\
\hline Romania & $\hat{\mathrm{z}}_{\mathrm{ROt}}=19.4683+0.0288759 * \mathrm{t}^{2}$ & 0.813273 & 2.437 \\
\hline Slovenia & $\hat{\mathrm{z}}_{\mathrm{SIt}}=30.36-0.0681818 * \mathrm{t}^{2}+1.17727 * \mathrm{t}$ & 0.911859 & 1.438 \\
\hline Slovakia & $\hat{\mathrm{z}}_{\mathrm{SKt}}=30.0733+0.453939 * \mathrm{t}$ & 0.854230 & 1.849 \\
\hline Finland & $\hat{\mathrm{z}}_{\mathrm{FIt}}=40.765-0.0443182 * \mathrm{t}^{2}+0.918409 * \mathrm{t}$ & 0.963867 & 0.671 \\
\hline Sweden & $\hat{\mathrm{z}}_{\mathrm{SEt}}=49.34+0.427273 * \mathrm{t}$ & 0.990293 & 0.263 \\
\hline United Kingdom & $\hat{\mathrm{z}}_{\mathrm{GBt}}=46.3967-0.044697 * \mathrm{t}^{2}+0.693485 * \mathrm{t}$ & 0.693220 & 1.090 \\
\hline
\end{tabular}

Source: own calculations based on Eurostat's database, https://ec.europa.eu/eurostat/data/database, Retrieved on September 11, 2018.

Due to the volume restrictions, the article will not present forecasts for all EU countries. It was decided to present only selected countries - Innovation Leaders (Denmark, Finland, Sweden, and the United Kingdom), Modest Innovators (Romania, and Bulgaria), and the neighboring countries of Poland in the Innovation Scoreboard ranking (Croatia, and Latvia).

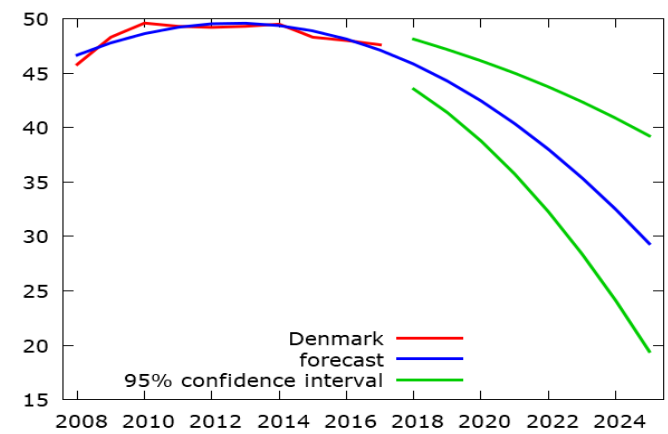

Figure 1. The participation of the KIS sector in employment in Denmark (data for 2008-2017 and the forecast for 2018-2025)

Source: own calculations based on Eurostat's database, https://ec.europa.eu/eurostat/data/database, Retrieved on September 11, 2018.

Starting with the best-performing countries in creating and implementing innovation, it can be seen that (excluding Sweden) the forecast foresees that the share of the KIS sector in total employment will decrease. The 'glass ceiling' for Denmark has been the level of $50 \%$ share of KIS in total employment, for Finland $-46 \%$, for the United Kingdom - also $50 \%$ (Figures 1-4).

In the case of the least-performing group of innovations, the forecast shows that the KIS sector in Bulgaria will hardly exceed the level of $32 \%$ share in the employment. In turn, Romania, in spite of the projected continuous development of the KIS sector, will not exceed $30 \%$ share in total employment (Figures 5-6). 


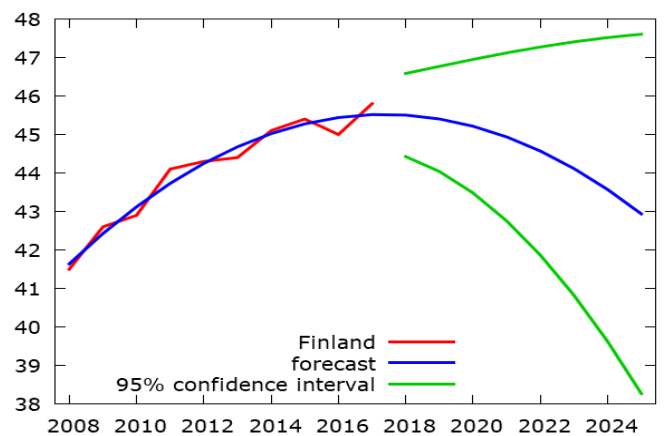

Figure 2. The participation of the KIS sector in employment in Finland

(data for 2008-2017 and the forecast for 2018-2025)

Source: own calculations based on Eurostat's database, https://ec.europa.eu/eurostat/data/database, Retrieved on September 11, 2018.

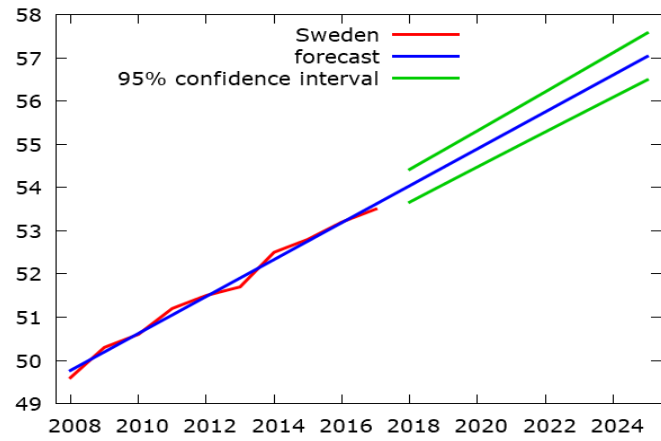

Figure 3. The participation of the KIS sector in employment in Sweden

(data for 2008-2017 and the forecast for 2018-2025)

Source: own calculations based on Eurostat's database, https://ec.europa.eu/eurostat/data/database, Retrieved on September 11, 2018.

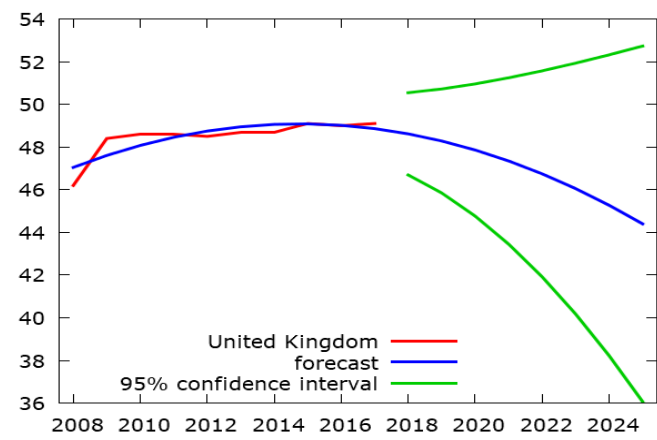

Figure 4. The participation of the KIS sector in employment in the United Kingdom

(data for 2008-2017 and the forecast for 2018-2025)

Source: own calculations based on Eurostat's database, https://ec.europa.eu/eurostat/data/database, Retrieved on September 11, 2018. 


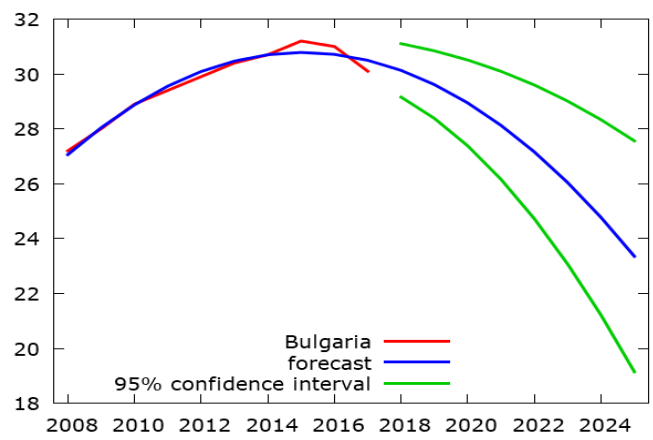

Figure 5. The participation of the KIS sector in employment in Bulgaria (data for 2008-2017 and the forecast for 2018-2025)

Source: own calculations based on Eurostat's database, https://ec.europa.eu/eurostat/data/database, Retrieved on September 11, 2018.

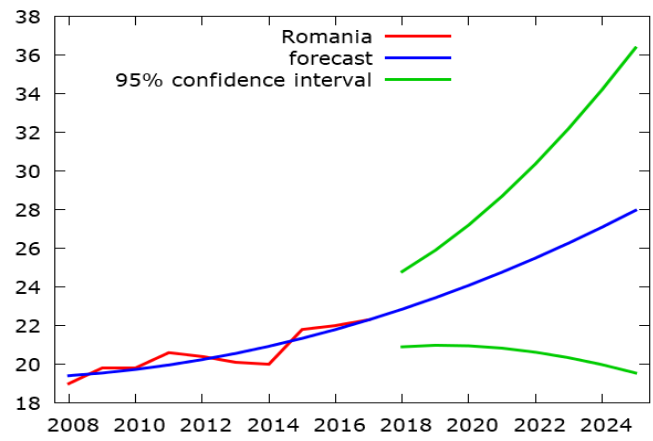

Figure 6. The participation of the KIS sector in employment in Romania (data for 2008-2017 and the forecast for 2018-2025)

Source: own calculations based on Eurostat's database, https://ec.europa.eu/eurostat/data/database, Retrieved on September 11, 2018.

Poland and countries similar to Poland in terms of ranking on the Innovation Scoreboard 2018 are characterised by diversified trends in KIS development. Poland most likely (as previously described Bulgaria) will not exceed the level of $32 \%$ of the KIS sector in total employment. The observed development of knowledge-intensive services in recent years has slowed down, and, according to the constructed forecast, reached its maximum. In turn, Croatia and Latvia are characterised by a growing trend line of the share of KIS in total employment. In the years 2008-2017 these countries were characterised by a rapid growth of this sector (an increase in the share of KIS in total employment by 7.4 and 5.1 percentage points, respectively), which allows to determine that achieving the $40 \%$ share of KIS in total employment by the year 2025 is possible (Figures 7-9).

Extending the reflection on the maximum share of the KIS sector in employment across all the EU countries, using only historical data (not forecasts), we may notice the existence of several 'glass ceilings'. The first group consists of countries where the share of the KIS sector in employment does not exceed 32-33\% over the period 2008-2017. 


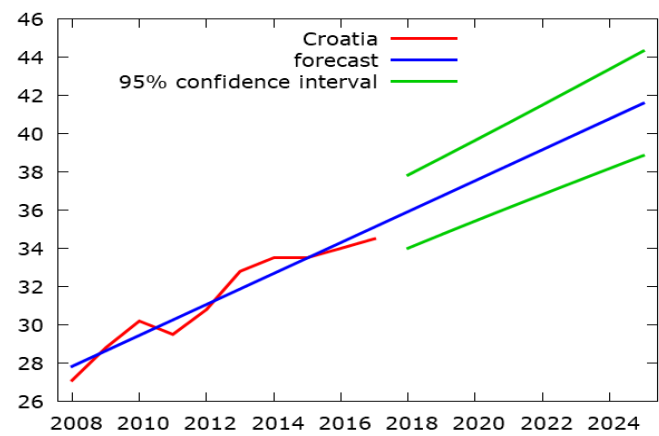

Figure 7. The participation of the KIS sector in employment in Croatia

(data for 2008-2017 and the forecast for 2018-2025)

Source: own calculations based on Eurostat's database, https://ec.europa.eu/eurostat/data/database, Retrieved on September 11, 2018.

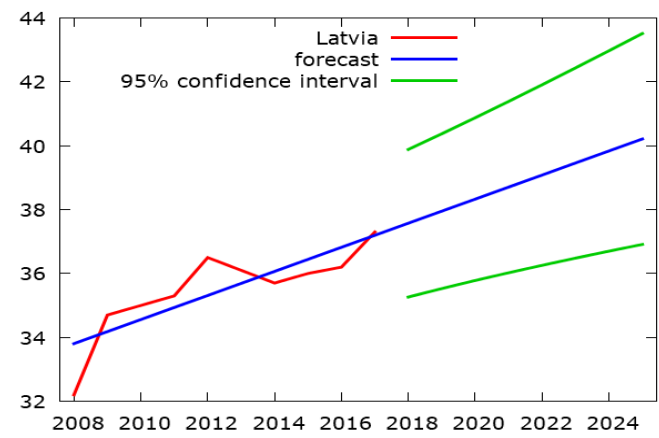

Figure 8. The participation of the KIS sector in employment in Latvia

(data for 2008-2017 and the forecast for 2018-2025)

Source: own calculations based on Eurostat's database, https://ec.europa.eu/eurostat/data/database, Retrieved on September 11, 2018.

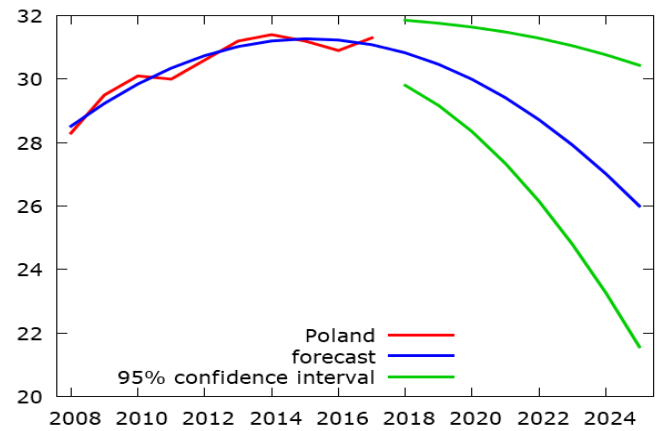

Figure 9. The participation of the KIS sector in employment in Poland

(data for 2008-2017 and the forecast for 2018-2025)

Source: own calculations based on Eurostat's database, https://ec.europa.eu/eurostat/data/database, Retrieved on September 11, 2018. 
These are Bulgaria, the Czech Republic, and Poland, moderate or modest innovators. The second group brings together countries where the share of the KIS sector in employment does not exceed 35-37\%: Estonia, Greece, Spain, Croatia, Italy, Latvia, Lithuania, Hungary, Portugal, Slovenia, and Slovakia. Almost all countries in this group (except for Slovenia) are moderate innovators. Another 'glass ceiling' is observed at the level of $40 \%$. This level is approached, but not significantly exceeded, by Germany, Cyprus, Austria, as well as the EU as a whole, and also the Eurozone. The sector's share in employment for the fourth group is $45-47 \%$. This includes Ireland, France, Malta, the Netherlands, and Finland strong innovators and innovation leaders. The level of $50 \%$ share of the KIS sector in total employment is the 'glass ceiling' for Belgium, Denmark, and the United Kingdom, also strong innovators and innovation leaders. This level is exceeded only in Sweden and Luxembourg. In the analysed years, Luxembourg was characterised by an extremely high share of KIS in total employment, reaching up to 58\% in the year 2014. In recent years, however, a significant reduction in employment in the KIS sector could be observed (to $48.5 \%$ in 2017). It can be predicted that in the future a similar fate will be shared by Sweden, which, for the time being, continuously develops its KIS sector. Given the parabolic shape of many constructed trend lines and the results of the constructed forecasts, it can be said that some of the analysed countries have already reached their maximum level of development of KIS, and some will reach it in the coming years. However, constant progress of knowledge-intensive services should not be expected.

Similar conclusions can be drawn by analysing productivity in knowledge-intensive services. In the years 2008-2014, the vast majority of the EU countries experienced a decrease in productivity defined as production of the sector per one-euro of personnel costs (Figure 10). During that period only in Belgium, Sweden, Finland, and the United Kingdom productivity increased (by $11 \%, 4 \%, 3 \%, 2 \%$, respectively). Such results are not surprising. Tassey (2004) pointed out that knowledge-based services are at risk of a decrease in productivity. This is due to the fact that they typically represent the final stage in a system of products related to consumption (e.g., communication, marketing, or trade).

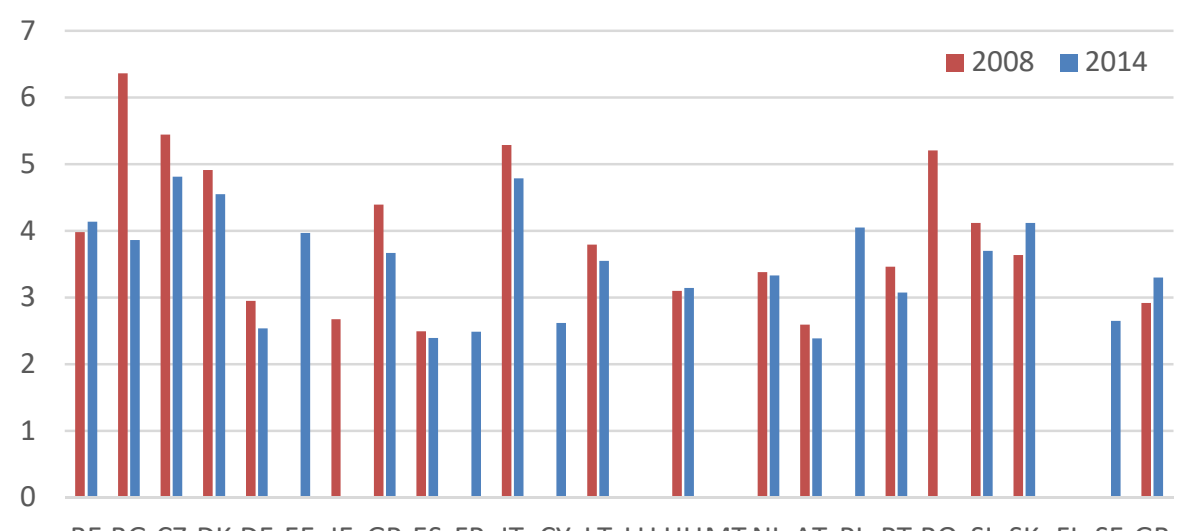

BE BG CZ DK DE EE IE GR ES FR IT CY LT LU HUMT NL AT PL PT RO SI SK FI SE GB

Figure 10. Productivity in knowledge-intensive high-technology services in the EU countries in 2008-2014

Source: own calculations based on Eurostat's database, https://ec.europa.eu/eurostat/data/database, Retrieved on September 11, 2018. 
What needs to be acknowledged is the fact that not all jobs in the knowledge intensive services sector are innovative, or actually knowledge intensive. To demonstrate this we compared some aspects of working conditions in two sectors: Financial (and other services) and Commerce and Hospitality (Figure 11). It can be observed that, depending on the aspect, only $50-80 \%$ of the jobs in Financial Services demand some form of knowledge processing. On the other hand, those figures are significantly lower for Commerce and Hospitality sector, so while it can be said that the KIS sector is not fully knowledge-intensive, it is still much more knowledge-intensive than other services.

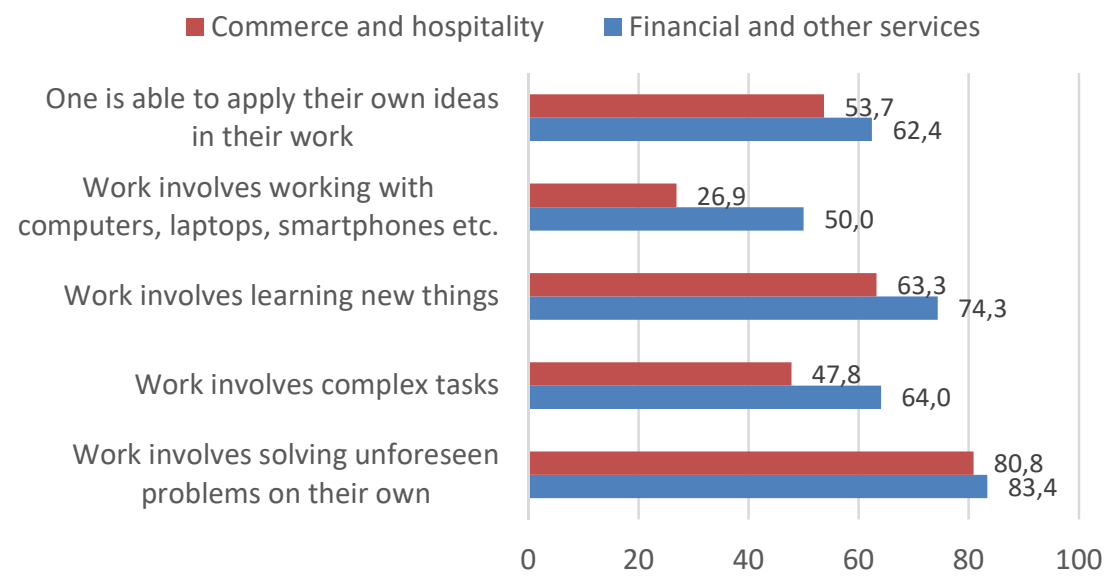

Figure 11. Percentage of respondents agreeing with knowledge-related statements concerning their workplace in $\mathbf{2 0 1 5}$ (average for the EU countries, Albania, the former Yugoslav Republic of Macedonia, Montenegro, Serbia, Turkey, Norway, and Switzerland)

Source: own calculations based on the European Working Conditions Survey (EWCS), https://www.eurofound.europa.eu/surveys/european-working-conditions-surveys, Retrieved on December 17, 2018.

Focusing on Poland, it should be emphasized once again that although in the years 20082017 the share of the KIS sector in total employment increased by three percentage points, the pace of these changes slows down, and currently the forecasts do not give it a chance to catch up to the countries - innovation leaders in this area. The declining efficiency is not conducive to the development of the KIS sector in Poland (-14\% in the years 2008-2014), but this trend is observed in most EU countries, and the efficiency in Poland remains higher than the EU average (5.20-euro of production for 1 euro of personnel cost to 3.73 euro in EU).

\section{CONCLUSIONS}

The study examined the design of knowledge-based business services in selected European countries. The EU-15 countries were characterised by a higher level of use of KIS and innovation than the EU-12 countries. In most EU countries, efficiencies in the KIS sector may fall; this is due to decreasing performance in Europe and the growing competition of non-EU outsourcing companies (e.g. in India), where costs are low.

In the case of Poland, the development of KIS also depends on the demand for innovative services, even the 'innovation climate.' In Poland, low spending on research 
and development continues, despite the extensive participation of people with higher education in the labour market, resulting in a significant mismatch between the skills of workforce and business needs.

However, weak signals suggesting a break in the trends presented can be seen. In Europe, this signal is the economic growth that eventually appears after the financial and debt crisis. With a demand-side mechanism, economic growth can revive the KIS sector. In particular, in Poland a significant influx of immigrant workers from non-EU countries (mainly Ukraine) can reduce staff costs in the KIS sector. Migrant workers tend to concentrate in larger cities, and many of them are attending local schools for higher education. This skilled workforce finds employment in outsourcing companies located in Poland, as opposed to previous years, when outsourcing companies moved to non-EU countries seeking lower costs.

The test carried out was not free from research limitations. It should be noted that the time series used to construct the projections were limited due to the availability of data concerning the EU's knowledge-intensive sectors; this can affect the accuracy of the results.

It can be concluded that the future standard of living for citizens in the EU will depend heavily on the KIS sector and the services sector. Based on the findings, it can be considered that it is essential that policymakers and governments put more emphasis on the development of the sector, notably by offering financial support, incentives and building a favourable political and economic environment for the functioning of KIS and knowledge transfer process. Besides, the development of a knowledge-based economy should also intensify the development of the information and communication sector (ICT). The results of the study can be a signal for innovation policy that it should not only target R\&D activities, but also support the development of KIS and innovation systems. It should also be noted that the current technological advances not only allow but also determine the implementation of activities related to the use of artificial intelligence and robotics in organisations. This will be a competitive advantage by reducing the cost of doing business, while at the same time increasing the efficiency of investment. However, it should be remembered that while the introduction of artificial intelligence undoubtedly contributes to the growth of GDP, it is not possible to downplay ethical issues or the consequences of the social introduction of new technologies.

Concluding, it should be stressed that the providers of business services have a relatively high potential to create innovative solutions in their activities. They are quite well prepared for both the infrastructure and the personnel side. There are no significant financial constraints in this respect, and innovation is regarded as important support for the processes of market competition.

Unexpectedly, however, the market can also hinder innovation development in KIS. Many companies using these services are more valued for their proven, less risk-based solutions. Inherent barriers in customer awareness seem to be the most difficult to overcome, and their recognition requires to conduct research among managers of companies using knowledge-intensive services.

We hope that our article will be an inspiration for further scientific research in the topic of KIS. Due to research limitations we focused only on the main components of the KIS development in the EU countries. The most important questions that should be addressed in the future concern the following issues:

- What creates the glass ceiling in the KIS sector? 
- Could the decreases in KIS employment in innovation leader countries be due to automation and $\mathrm{Al}$ development?

- What are the possible factors that could help a country to break the forecasted trend?

\section{REFERENCES}

Baláž, V. (2004). Knowledge-intensive business services in transition economies. The Service Industries Journal, 24(4), 83-100, https://doi.org/10.1080/0264206042000275208

Baumol, W.J. (2002). Services as leaders and the leader of the services. In J. Gadrey \& F. Gallouj (Eds.), Productivity, Innovation and Knowledge in Services: New Economic \& Socio-Economic Approaches (pp. 147-163), Cheltenham, UK, Northampton, MA, USA: Edward Elgar Publishing..

Bettencourt, L.A., Ostrom, A.L., Brown, S.W., \& Roundtree, R.I. (2002). Client co-production in knowledge-intensive business services. California Management Review, 44(4), 100-128.

Bilderbeek, R., den Hertog, P., Marklund, G. \& Miles, I. (1998). Services in Innovation Knowledge Intensive Business Services (KIBS) as Co-producers of Innovation, Synthesis Paper SI4S-S3/ 1998. Oslo: Studies in Technology, Innovation and Economic Policy Group, 1-59.

Braga, A., Marques, C.S., \& Serrasqueiro, Z. (2017). Internationalisation Strategy of Knowledge-Intensive Business Services. Journal of the Knowledge Economy, Springer; Portland International Center for Management of Engineering and Technology (PICMET), 9(2), June, 359-377. https://doi.org/10.1007/s13132-017-0461-5

Brenner, T., Capasso, M., Duschl, M., Frenken, K., \& Treibich, T. (2018). Causal relations between knowledge-intensive business services and regional employment growth. Regional Studies, 52(2), 172-183, https://doi.org/10.1080/00343404.2016.1265104

Castaldi, C. (2009). The relative weight of manufacturing and services in Europe: An innovation perspective. Technological Forecasting and Social Change, 76(6), 709-722. https://doi.org/10.1016/j.techfore.2008.08.001

Castellacci, F. (2008). Technological paradigms, regimes and trajectories: Manufacturing and service industries in a new taxonomy of sectoral patterns of innovation. Research Policy, 37(6), 978994. https://doi.org/10.1016/j.respol.2008.03.011

Desmarchelier, B., Djellal, F., \& Gallouj, F. (2013). Knowledge intensive business services and long term growth. Structural Change and Economic Dynamics, 25, 188-205.

Doloreux, D., Shearmur, R., \& Rodriguez, M. (2015). Determinants of R\&D in knowledge-intensive business services firms, Economics of Innovation and New Technology, 391-404. https://doi.org/10.1080/10438599.2015.1067001

Doloreux, D., \& Shearmur, R. (2012). Collaboration, information and the geography of innovation in knowledge intensive business services, Journal of Economic Geography, 12(1), 79-105, https://doi.org/10.1093/jeg/lbr003

Dubosson, M., \& Fragniere, E. (2009). The Consequences of Information Overload in Knowledge Based Service Economies: An Empirical Research Conducted in Geneva. Service Science 1(1), 5662. https://doi.org/10.1287/serv.1.1.56

Gallego, J., \& Maroto, A. (2015). The Specialization in Knowledge-Intensive Business Services (KIBS) across Europe: Permanent Co-Localization to Debate. Regional Studies, 49(4), 644-664. https://doi.org/10.1080/00343404.2013.799762

Godlewska-Dzioboń, B., Klimczyk, P., \& Witoń, A. (2018). Determinatives of Employment Changes in the Polish Service Sector Between 2005 and 2017. In A. Nalepka, A. Ujwary-Gil (Eds), Business and Non-profit Organizations Facing Increased Competition and Growing Customers' Demands 
(pp. 519-534). Nowy Sącz; Nowy Targ: Wyższa Szkoła Biznesu - National-Louis University; Foundation for the Dissemination of Knowledge and Science 'Cognitione'.

Hertog, P. (2000). Knowledge intensive business services as co-producers of innovation. International Journal of Innovation Management, 4(4), 491-528.

J-Figueiredo, R., Vieira Neto, J., Gonçalves Quelhas, O.L., \& de Matos Ferreira, J.J. (2017). Knowledge Intensive Business Services (KIBS): Bibliometric Analysis And Their Different Behaviors In The Scientific Literature. INMR - Innovation \& Management Review, 14(3), 216-225. Retrieved from http://www.revistas.usp.br/rai/article/view/134958 on March 10, 2018.

Klaesson, J., \& Norman, T. (2015). Market potential and the employment growth of knowledge-intensive services: comparing different geographical resolutions. The Annals of Regional Science, 55(1), October, 157-185. https://doi.org/10.1007/s00168-015-0701-1

Masso, J., \& Vahter, P. (2012). The link between innovation and productivity in Estonia's services sector. Service Industries Journal, 32(16), 2527-2541. https://doi.org/10.1080/02642069. 2011.600444

Miles, I. (2005). Knowledge intensive business services: Prospects and policies. Foresight, 7(6), 3963, https://doi.org/10.1108/14636680510630939

Miles, I.D., Belousova, V., \& Chichkanov, N. (2018). Knowledge intensive business services: ambiguities and continuities. Foresight, 20(1), 1-26.

Miles, I., Kastrinos, N., Bilderbeek, R., den Hertog, P., Flanagan, K., Huntink, W., \& Bouman, M. (1995). Knowledge-Intensive Business Services: Users, Carriers and Sources of Innovation. European Innovation Monitoring System (EIMS) Publication, 15. European Commission, Brussels, 1-105.

Muller, E., \& Zenker, A. (2001). Business services as actors of knowledge transformation: The role of KIBS in regional and national innovation systems. Research Policy, 30(9), 1501-1516.

Musolesi, A., \& Huiban, J.P. (2010). Innovation and productivity in knowledge intensive business services. Journal of Productivity Analysis, 34, 63-81. https://doi.org/10.1007/s11123-009-0163-5

Pauceanu, A.M. (2015). Impact of knowledge intensive businesses services on the economic performance of sectors and regions in the UE. Africa Development and Resources Research Institute Journal, Ghana, West Africa, 8(2), 2343-6891.

Radovanović, N., Dmitrović, V., \& Žarkić Joksimović, N. (2017). From Knowledge to Innovation and Back: Empirical Testing of Knowledge-Intensive Industries in Serbia. Entrepreneurial Business and Economics Review, 5(3), 119-131. https://doi.org/10.15678/EBER.2017.050306

Rodriguez, M. (2014). Innovation, Knowledge Spillovers and High-Tech Services in European Regions. Inzinerine Ekonomika-Engineering Economics, 25(1), 31-39. https://doi.org/10.5755/j01.ee. 25.1.3207

Schricke, E., Zenker, A., \& Stahlecker, T. (2012). Knowledge-intensive (business) services in Europe, European Commission, EUR 25189 EN, Brussel, Retrieved from ec.europa.eu/research/innovation-union/pdf/knowledge_intensive_business_services_in_europe_2011. pdf on September 25, 2018.

Tassey, G. (2004). Policy Issues for R\&D investment in a knowledge-based economy. Journal of Technology Transfer, 29(2), 153-185.

Wilks, D.S. (2006). Statistical Methods in the Atmospheric Sciences. Burlington, MA: Academic Press, 1-630, Retrieved from http://danida.vnu.edu.vn/cpis/files/Books /Statistical\%20methods \%20in\%20the\%20atmospheric\%20sciences,\%20D.\%20Wilks\%20(2ed.,\%20I GS\%2091,\%20Elsev ier,\%202006)(ISBN\%200127519661)(649s).pdf on September 25, 2018.

Watkins, J.C. (2016). An Introduction to the Science of Statistics: From Theory to Implementation. Preliminary Edition, Tucson, AZ: University of Arizona, 1-429. Retrieved http://math.arizona.edu / jwatkins/statbook.pdf on December 18, 2018. 
Wolff, E. (2002). How stagnant are services? In J. Gadrey \& F. Gallouj (Eds.), Productivity, innovation and knowledge in services: new economic and socio-economic approaches. (pp. 3-25), Cheltenham, UK, Northampton, MA, USA: Edward Elgar Publishing..

Wyszkowska-Kuna, J. (2016). Competitiveness of the New European Union Member States in International Trade in Knowledge-intensive Business Services. Comparative Economic Research, 19(3), 5-26. https://doi.org/10.1515/cer-2016-0018

Ženka, J., Novotný, J., Slach, O., \& Ivan, I. (2017). Spatial Distribution of Knowledge-Intensive Business Services in a Small Post-Communist Economy. Journal of the Knowledge Economy, Springer; Portland International Center for Management of Engineering and Technology (PICMET), 8(2), June, 385-406. https://doi.org/10.1007/s13132-015-0260-9

The copyediting and proofreading of articles in English is financed in the framework and Higher Education of contract No. 913/P-DUN/2019 by the Ministry of Science and Higher Education Republicospoland of the Republic of Poland committed to activities aimed at science promotion.

This publication has been co-financed by the European Commission Representation in Poland. The European Commission, or any person acting on its behalf, is not responsible for the use of the information contained in this publication. This publication Commission reflects the views only of the authors, and the European Commission cannot be held responsible for any use which may be made of the information contained therein. 


\section{Authors}

The contribution share of authors is equal and amounted to $33 \%$ each of them.

\section{Bianka Godlewska-Dzioboń}

Master in Economics (Faculty of Economics, specialisation: Accountancy, Cracow University of Economics); PhD in Economics (Cracow University of Economics). Research interests include international trade, labour market and the structure of economy.

Correspondence to: Bianka Godlewska-Dzioboń PhD, Cracow University of Economics, ul. Rakowicka 27, 31-510 Kraków, Poland, e-mail: godlewsb@uek.krakow.pl

ORCID (1) http://orcid.org/0000-0001-9668-458X

\section{Piotr Klimczyk}

Master in Economics (Faculty of Economics, specialisation: Foreign Trade, Cracow University of Economics); PhD in Economics (Cracow University of Economics). Research interests include international trade, labour market and the structure of economy.

Correspondence to: Piotr Klimczyk, PhD, Cracow University of Economics, Theory of Economics Department, ul. Rakowicka 27, 31-510 Kraków, Poland, e-mail: klimczyp@uek.krakow.pl ORCID (i) http://orcid.org/0000-0001-9238-2744

\section{Agnieszka Witoń}

Master in Economics (specialisation: International Economics, Jagiellonian University in Cracow); $\mathrm{PhD}$ in Economics (Cracow University of Economics). Research interests include economic growth, socio-economic development, and knowledge-based economy.

Correspondence to: Agnieszka Witoń, PhD, Cracow University of Economics, Theory of Economics Department, ul. Rakowicka 27, 31-510 Kraków, Poland, e-mail: witona@uek.krakow.pl

ORCID (1) http://orcid.org/0000-0002-4024-2851

\section{Acknowledgements and Financial Disclosure}

The authors would like to thank the anonymous reviewers and the Thematic Editor of EBER for their useful comments, which allowed to increase the quality of this article. The research has been co-financed from funds allocated to the Faculty of Economics and International Relations of the Cracow University of Economics, as part of subsidies for maintaining research potential.

This article has been presented as the academic paper at the scientific conference GLOB2018: "Globalization and Regionalization in the Contemporary World: Competitiveness, Development, Sustainability" organized in Kraków on 21-22 September 2019.

\section{Copyright and License}

This article is published under the terms of the Creative Commons Attribution - NoDerivs (CC BY-ND 4.0) License http://creativecommons.org/licenses/by-nd/4.0/ 